\title{
Zimmermannella helvola gen. nov., sp. nov., Zimmermannella alba sp. nov., Zimmermannella bifida sp. nov., Zimmermannella faecalis sp. nov. and Leucobacter albus sp. nov., novel members of the family Microbacteriaceae
}

\author{
Yi-Chueh Lin, ${ }^{1}$ Kazunori Uemori, ${ }^{1}$ Dominique A. de Briel, ${ }^{2}$ \\ Vallapa Arunpairojana ${ }^{3}$ and Akira Yokota ${ }^{1}$ \\ ${ }^{1}$ Laboratory of Bioresources, Institute of Molecular and Cellular Biosciences, The University of \\ Tokyo, 1-1-1 Yayoi, Bunkyo-ku, Tokyo 113-0032, Japan \\ ²DADB, Service de Microbiologie, Hôpital Louis-Pasteur, Hôpitaux Civils, 68024 Colmar, \\ France \\ ${ }^{3}$ Thailand Institute of Scientific and Technological Research (TISTR), 196 Phahonyothin Road,
Chatuchak, Bangkok 10900, Thailand
}

Correspondence

Yi-Chueh Lin

yilin@genes.nig.ac.jp

\section{INTRODUCTION}

The family Microbacteriaceae currently contains 15 genera, which are characterized by B-type peptidoglycan (Schleifer \& Kandler, 1972) and unsaturated major menaquinones (Collins \& Jones, 1981). At first, the family Microbacteriaceae was proposed to accommodate the genera Agromyces,

Published online ahead of print on 16 April 2004 as DOI 10.1099/ ijs.0.02741-0.

Abbreviation: DAB, 2,4-diaminobutyric acid.

The GenBank/EMBL/DDBJ accession numbers for the 16S rRNA gene sequences determined in this study are given in Fig. 2.
Aureobacterium, Clavibacter, Curtobacterium and Microbacterium (Park et al., 1993). On the basis of 16S rRNA gene sequence data, the family was found to accommodate the genera Agrococcus and Rathayibacter in addition to the above-mentioned genera (Stackebrandt et al., 1997). The genera Leucobacter (Takeuchi et al., 1996) and Cryobacterium (Suzuki et al., 1997) have also been shown to represent branches within the family Microbacteriaceae. It has been proposed that the genera Aureobacterium and Microbacterium should be united in the redefined genus Microbacterium on the basis of 16S rRNA gene sequence data and chemotaxonomic data (Takeuchi \& Hatano, 1998). The new genera Frigoribacterium (Kämpfer et al., 2000) and 
Subtercola (Männistö et al., 2000) have been reported as psychrophilic members of the family. The genera Leifsonia (Evtushenko et al., 2000), Agreia (Evtushenko et al., 2001), Mycetocola (Tsukamoto et al., 2001), Okibacterium (Evtushenko et al., 2002) and Plantibacter (Behrendt et al., 2002) have also been shown to be members of the family Microbacteriaceae.

The aim of the present study was to identify the seven isolates collected from various sources in the culture collection of the Institute of Applied Microbiology, University of Tokyo (Tokyo, Japan). Here we describe the physiological, chemotaxonomic and phylogenetic characteristics of these strains. On the basis of these data, six strains are proposed as constituting a novel genus, Zimmermannella gen. nov., containing four new species; the other strain is proposed to be a novel species, Leucobacter albus sp. nov.

\section{METHODS}

Bacterial strains. Seven strains isolated from various sources and obtained from the above-mentioned culture collection are listed in Table 1. Strains IAM $14848^{\mathrm{T}}$ and IAM $14851^{\mathrm{T}}$ were isolated in our laboratory from soil from Thailand. The medium used for isolation was nutrient agar (Difco) containing $20 \mu \mathrm{g}$ polymyxin $\mathrm{B} \mathrm{ml} \mathrm{m}^{-1}$ and $100 \mu \mathrm{g}$ cycloheximide $\mathrm{ml}^{-1}$ and was incubated at $27^{\circ} \mathrm{C}$ for 7 days. After colonies had formed, the Gram-positive strains were picked up. With the exception of strain IAM $14724^{\mathrm{T}}$, the strains were grown in peptone/yeast extract broth supplemented with brain heart infusion (BHI) (Difco), i.e. $1 \%$ peptone, $0 \cdot 2 \%$ yeast extract, $0.2 \%$ $\mathrm{NaCl}, 0 \cdot 2 \%$ D-glucose, $0 \cdot 2 \% \mathrm{BHI}, 1 \cdot 5 \%$ agar (pH 7.0) (PY-BHI medium) and nutrient agar medium containing $0.5 \%$ peptone, $0 \cdot 3 \%$ meat extract, $0 \cdot 3 \% \mathrm{NaCl}$ and $1 \cdot 5 \%$ agar $(\mathrm{pH} 7 \cdot 0$ ). Strain IAM $14724^{\mathrm{T}}$ was grown in PY-BHI medium to which $0 \cdot 1 \%$ $\mathrm{MgSO}_{4} \cdot 7 \mathrm{H}_{2} \mathrm{O}$ had been added. All strains were cultured aerobically at $30^{\circ} \mathrm{C}$.

Morphological, physiological and biochemical characteristics. Cell morphology was determined by using cells grown on PY-BHI agar. Each sample used for scanning electron microscopy with a model S-4500 scanning electron microscope (Hitachi) was prepared by fixing cells with $1 \%$ glutaraldehyde and then dehydrating them with a graded acetone series and then in a Hitachi model HCP-2 critical point drying apparatus. Motility was determined by the hanging drop method. Unless otherwise indicated, all tests were performed at $25^{\circ} \mathrm{C}$. Catalase activity was determined by bubble formation in a $3 \% \mathrm{H}_{2} \mathrm{O}_{2}$ solution. Oxidase activity was determined by the oxidation of $1 \%$ tetramethyl-p-phenylenediamine on filter paper. Acid production from carbohydrates, assimilation of carbohydrates, nitrate reduction and the hydrolysis of aesculin and gelatin were studied by using API $50 \mathrm{CH}$ and API $20 \mathrm{NE}$ strips (bioMérieux).

Chemical analyses. Cell walls were prepared from approximately $500 \mathrm{mg}$ (dry weight) bacterial cells as described by Schleifer \& Kandler (1972). Amino acids in an acid hydrolysate of the cell walls were identified by two-dimensional descending chromatography on cellulose TLC plates (Tokyo Kasei) by the method of Harper \& Davis (1979) and by HPLC, as their phenylthiocarbamoyl derivatives, with a model LC-6AD HPLC apparatus (Shimadzu) equipped with a Wakopak WS-PTC column (Wako Pure Chemical Industries, 1989). Analysis of enantiomeric diamino acid isomers was performed according to Sasaki et al. (1998). Cell-wall sugars were analysed as described by Mikami \& Ishida (1983). Fatty acids were extracted from dried cells, purified and then examined as described previously (Yokota et al., 1993). The glycolate test was performed by using the method of Uchida \& Aida (1977).

G+C content and DNA-DNA relatedness. Isolation and purification of chromosomal DNA and estimation of the DNA G + C content were performed by using the methods of Takagi et al. (1993). DNA relatedness values were determined as described by Ezaki et al. (1989).

$16 S$ rRNA gene sequence analyses. The $16 \mathrm{~S}$ rRNA gene was amplified by a PCR using prokaryotic $16 \mathrm{~S}$ rRNA gene universal primers $8 \mathrm{~F}$ (5'-AGAGTTTGATCCTGGCTCAG-3') and 1510R (5'GGCTACCTTGTTACGA-3'). The PCR products were purified using a Sepharose $\mathrm{Cl}-2 \mathrm{~B}$ gel (Pharmacia). Sequencing reactions were performed using the ABI PRISM BigDye Terminator cycle sequencing ready reaction kit (Applied Biosystems). The primers used for sequencing were $8 \mathrm{~F}, 704 \mathrm{R}$ ( $5^{\prime}$-TCTACGCATTTCACC-3'), 520F ( $5^{\prime}$ CAGCAGCCGCCGTAATAC-3'), 1100R (5'-GGGTTGCGCTCGTTG-3'), 926F (5'-AAACTCAAAGGAATTGACGG-3') and 1510R. All PCRs were performed with a Perkin-Elmer Cetus model 9600 thermal cycler. Each extension product resulting from the sequencing reaction was purified through a Centri-Sep spin column (Applied Biosystems) and sequenced by using an ABI model $373 \mathrm{~S}$ automated DNA sequencer.

Table 1. Strains used in this study

CIP, Collection de l'Institut Pasteur, Paris, France; TISTR, Culture Collection of the Thailand Institute of Scientific and Technological Research, Bangkok, Thailand; ATCC, American Type Culture Collection, Manassas, VA, USA; IFO, Institute for Fermentation, Osaka, Japan.

\begin{tabular}{|c|c|c|}
\hline Strain & Other strain designations & Source of isolation \\
\hline Z. helvola IAM $14726^{\mathrm{T}}$ & $\begin{array}{l}\text { 'Brevibacterium helvolum' (Zimmermann) Lochhead } \\
\text { DSM 20419, IFO 15775, TISTR } 1509\end{array}$ & Butter \\
\hline Z. alba IAM $14724^{\mathrm{T}}$ & A59836 ${ }^{\mathrm{T}}$ (D. A. de Briel), IFO $15616^{\mathrm{T}}$, TISTR $1510^{\mathrm{T}}$ & Urine (Strasbourg University Hospital, France) \\
\hline Z. bifida IAM $14848^{\mathrm{T}}$ & Isolate $\mathrm{S} 7-7^{\mathrm{T}}$, TISTR $1511^{\mathrm{T}}$ & Soil of Nakhon Ratchasima Province, Thailand \\
\hline Z. bifida IAM 15028 & CIP 102131, IFO 15777, TISTR 1512 & Human blood \\
\hline Z. bifida IAM 15029 & B4657 (D. A. de Briel), IFO 15614, TISTR 1513 & Wound (Strasbourg University Hospital, France) \\
\hline Z. faecalis IAM $15030^{\mathrm{T}}$ & $\begin{array}{l}\text { [Corynebacterium bovis] ATCC } 13722^{\mathrm{T}} \text {, IFO } 15706^{\mathrm{T}} \text {, } \\
\text { TISTR } 1514^{\mathrm{T}}\end{array}$ & Cow faeces \\
\hline L. albus IAM $14851^{\mathrm{T}}$ & Isolate $\mathrm{F}-8^{\mathrm{T}}$, TISTR $1515^{\mathrm{T}}$ & Soil of Uthai Thani Province, Thailand \\
\hline
\end{tabular}


Phylogenetic analysis. The multiple alignment of sequences, calculation of nucleotide substitution rates $\left(K_{\text {nuc }}\right.$ values; Kimura, 1980 ), construction of a neighbour-joining phylogenetic tree (Saitou \& Nei, 1987) and bootstrap analysis with 1000 replicates for evolution of phylogenetic tree topology (Felsenstein, 1985) were carried out with the CLUSTAL $\mathrm{W}$ multiple sequence alignment program (Thompson et al., 1994). The NCBI and DDBJ accession numbers used in this analysis are given in Fig. 2. Arthrobacter globifomis ATCC $8010^{\mathrm{T}}(\mathrm{M} 23411)$ and Cellulomonas flavigena ATCC $482^{\mathrm{T}}$ (X79463) were used as the outgroup.

\section{RESULTS}

\section{Morphological, physiological and biochemical characteristics}

All of the strains were Gram-positive, non-sporulating and aerobic. Cells of strain IAM $14726^{\mathrm{T}}$ usually occurred in pairs with two rings on one side (Fig. 1a). Cells of strains IAM $14726^{\mathrm{T}}$, IAM $14724^{\mathrm{T}}$, IAM $15030^{\mathrm{T}}$ and IAM $14851^{\mathrm{T}}$ were short rods, $0 \cdot 3-0 \cdot 4 \mu \mathrm{m}$ wide and $0 \cdot 5-1 \cdot 1 \mu \mathrm{m}$ long;
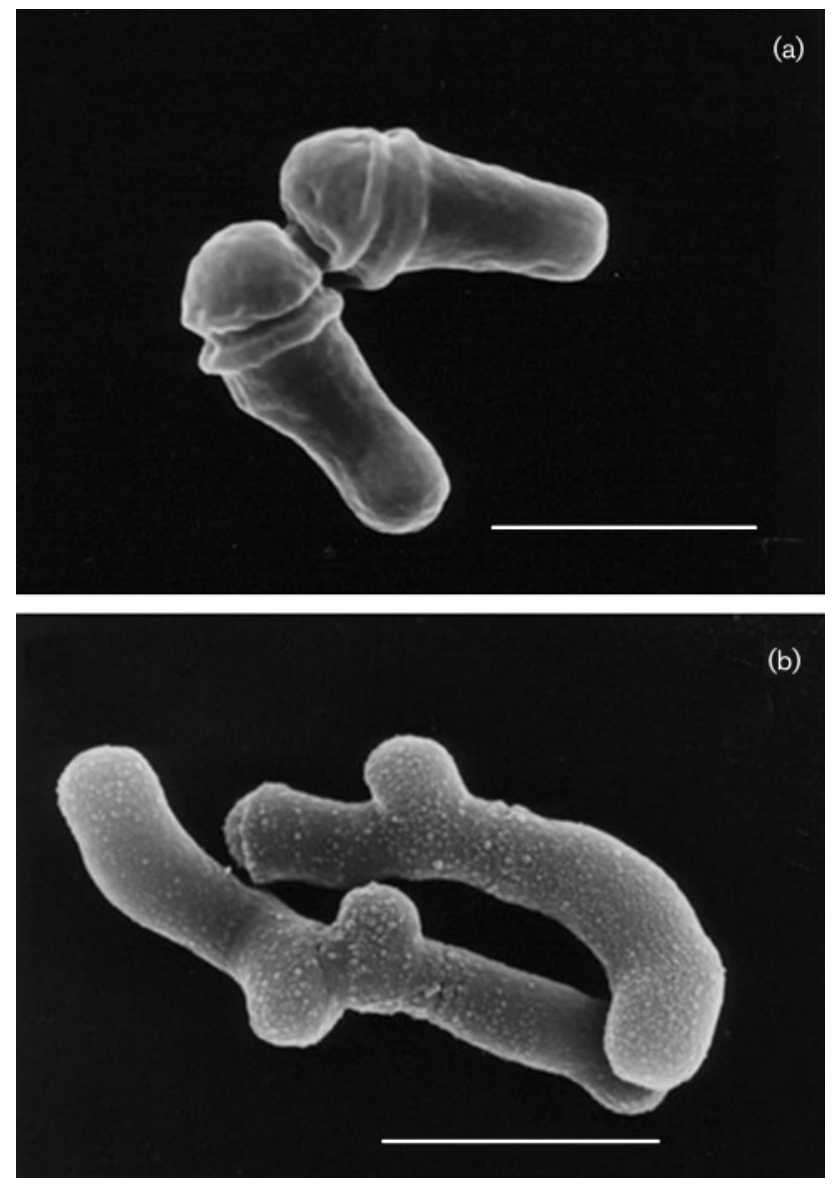

Fig. 1. Scanning electron micrographs of cells of Zimmermannella strains. (a) Z. helvola IAM $14726^{\top}$, showing rod-shaped cells with two rings in one side. (b) Z. bifida IAM $14848^{\top}$, showing branched cells. Bars, $1 \mu \mathrm{m}$. cells of IAM $14848^{\mathrm{T}}$, IAM 15028 and IAM 15029 were rods, $0 \cdot 3-0 \cdot 4 \mu \mathrm{m}$ wide and $1 \cdot 5-3 \mu \mathrm{m}$ long in PY-BHI medium. Cells of strain IAM $14848^{\mathrm{T}}$ had a branched shape (Fig. 1b). The cells of all strains formed round, smooth, convex, white colonies. All strains were catalase-positive and negative for nitrate reduction (Table 2). Strains IAM $14848^{\mathrm{T}}$, IAM 15028, IAM 15029 and IAM $14724^{\mathrm{T}}$ were positive for alkaline phosphatase activity. Strains IAM $14726^{\mathrm{T}}$ and IAM $14848^{\mathrm{T}}$ produced acid from rhamnose, and strain IAM 15028 produced acid from ribose. Strain IAM $15030^{\mathrm{T}}$ produced acid from D-glucose, D-fructose, D-mannose, rhamnose, inositol and mannitol. Strain IAM $14851^{\mathrm{T}}$ produced acid from glycerol, ribose and L-fucose.

\section{Chemical analyses}

The strains were divided into four groups according to their major menaquinone compositions (Table 3). Strains IAM $14726^{\mathrm{T}}$ and IAM $15030^{\mathrm{T}}$ had MK-9 as the major menaquinone, IAM $14724^{\mathrm{T}}$ had MK-10, while strains IAM $14848^{\mathrm{T}}$, IAM 15028 and IAM 15029 had MK-8 and MK-9. In strain IAM $14851^{\mathrm{T}}$, MK-11 was the major menaquinone. The cellular fatty acids of all of the strains mainly comprised

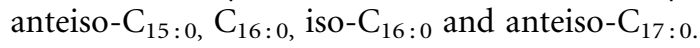

The diamino acid in the peptidoglycan of the strains was 2,4-diaminobutyric acid (DAB) (Table 3). Most of the strains contained L-DAB, except for IAM $15030^{\mathrm{T}}$ and IAM $14726^{\mathrm{T}}$. Strain IAM $15030^{\mathrm{T}}$ contained homoserine in addition to L-DAB. Strain IAM $14726^{\mathrm{T}}$ contained L-DAB and D-DAB. The peptidoglycan of strain IAM $14726^{\mathrm{T}}$ contained glutamate, glycine, alanine and L-DAB in molar ratios of $1 \cdot 0: 1 \cdot 0: 0 \cdot 8: 1 \cdot 8$, corresponding to type $\mathrm{B} 2 \gamma$ of Schleifer \& Kandler (1972). Those of strains IAM $14724^{\mathrm{T}}$, IAM $14848^{\mathrm{T}}$, IAM 15028 and IAM 15029 contained these amino acids in nearly the same ratios. The peptidoglycan of strain IAM $15030^{\mathrm{T}}$ contained glutamate, glycine, alanine, L-DAB and homoserine in molar ratios of $1 \cdot 0: 1 \cdot 9: 0 \cdot 8: 0 \cdot 9: 0 \cdot 2$. The peptidoglycan of strain IAM $14851^{\mathrm{T}}$ contained glutamate, glycine, alanine, L-DAB and $\gamma$ aminobutyric acid in molar ratios of $1 \cdot 0: 1 \cdot 1: 1 \cdot 8: 0 \cdot 8: 0 \cdot 7$.

The cell-wall sugars of all the strains are shown in Table 3. The cell-wall sugars of strain IAM $14726^{\mathrm{T}}$ were rhamnose and 6-deoxytalose, while those of strain IAM $14724^{\mathrm{T}}$ were rhamnose, 6-deoxytalose and glucose. The cell-wall sugars of strains IAM $14848^{\mathrm{T}}$, IAM 15028 and IAM 15029 were rhamnose and glucose, that of strain IAM $15030^{\mathrm{T}}$ was rhamnose, and those of strain IAM $14851^{\mathrm{T}}$ were rhamnose, galactose and glucose.

\section{Phylogenetic analysis of the 16S rRNA gene}

Nearly complete 16S rRNA gene nucleotide sequences (1480 bp) were determined for the seven strains. The phylogenetic tree constructed using the neighbour-joining method and $K_{\text {nuc }}$ values clearly shows that strain IAM $14851^{\mathrm{T}}$ is in the same cluster as Leucobacter komagatae IAM $1093^{\mathrm{T}}$, with the other six strains occupying a distinct 
Table 2. Phenotypic characteristics of isolates

Strains: 1, Z. helvola gen. nov., sp. nov. IAM $14726^{\mathrm{T}}$; 2, Z. alba sp. nov. IAM $14724^{\mathrm{T}} ; 3-5, Z$. bifida sp. nov. strains IAM $14848^{\mathrm{T}}$ (3), IAM 15028 (4) and IAM 15029 (5); 6, Z. faecalis sp. nov. IAM $15030^{\mathrm{T}} ; 7$, L. komagatae IAM $1093^{\mathrm{T}} ; 8$, L. albus sp. nov. IAM $14851^{\mathrm{T}}$.

\begin{tabular}{|c|c|c|c|c|c|c|c|c|}
\hline Characteristic & 1 & 2 & 3 & 4 & 5 & 6 & 7 & 8 \\
\hline Oxidase activity & + & - & - & - & - & + & - & - \\
\hline Nitrate reduction & - & - & - & - & - & - & - & - \\
\hline Alkaline phosphatase & - & + & + & + & + & - & - & - \\
\hline Hydrolysis of gelatin & - & - & - & - & - & - & + & - \\
\hline \multicolumn{9}{|l|}{ Acid production from: } \\
\hline Glycerol & - & - & - & - & - & - & + & + \\
\hline Ribose & - & - & - & + & - & - & - & + \\
\hline D-Glucose & - & - & - & - & - & + & - & - \\
\hline D-Fructose & - & - & - & - & - & + & - & - \\
\hline D-Mannose & - & - & - & - & - & + & - & - \\
\hline Rhamnose & + & - & + & - & - & + & - & - \\
\hline Inositol & - & - & - & - & - & + & - & - \\
\hline Mannitol & - & - & - & - & - & + & - & - \\
\hline L-Fucose & - & - & - & - & - & - & - & + \\
\hline
\end{tabular}

position in the family Microbacteriaceae with $100 \%$ bootstrap confidence (Fig. 2).

The level of 16S rRNA gene sequence similarity between the isolates IAM $14851^{\mathrm{T}}$ and L. komagatae IAM $1093^{\mathrm{T}}$ was $98 \cdot 2 \%$. Strains IAM $14726^{\mathrm{T}}$ and IAM $14724^{\mathrm{T}}$ showed $96 \cdot 1-96 \cdot 6 \% 16 \mathrm{~S}$ rRNA gene sequence similarity. The $16 \mathrm{~S}$
rRNA genes of IAM $14848^{\mathrm{T}}$, IAM 15028 and IAM 15029 showed $99 \cdot 6-99 \cdot 8 \%$ similarity to each other and 96-98.1\% sequence similarity to the other three strains. The $16 \mathrm{~S}$ rRNA gene of strain IAM $15030^{\mathrm{T}}$ showed $98 \%$ sequence similarity to those of strains IAM $14848^{\mathrm{T}}$, IAM 15028 and IAM 15029 , and $96 \cdot 3-96 \cdot 6 \%$ similarity to those of strains IAM $14726^{\mathrm{T}}$ and IAM $14724^{\mathrm{T}}$.

\section{G $+\mathbf{C}$ content and DNA-DNA relatedness}

The DNA G + C contents were $66 \mathrm{~mol} \%$ for strain IAM $14851^{\mathrm{T}}, 62 \mathrm{~mol} \%$ for strains IAM $14848^{\mathrm{T}}$, IAM 15028 and IAM 15029, $67 \mathrm{~mol} \%$ for strains IAM $15030^{\mathrm{T}}$ and IAM $14726^{\mathrm{T}}$ and $68 \mathrm{~mol} \%$ for strain IAM $14724^{\mathrm{T}}$ (Table 4 ). The levels of DNA relatedness were analysed, and the results are presented in Table 4 . Three strains, IAM $14848^{\mathrm{T}}$, IAM 15028 and IAM 15029, were found to have 75-82\% relatedness, while the other four strains showed little DNA relatedness. The DNA-DNA hybridization value between IAM $14851^{\mathrm{T}}$ and $L$. komagatae IAM $1093^{\mathrm{T}}$ was $40 \%$ (Table 4 ).

\section{DISCUSSION}

On the basis of phenotypic and genotypic characteristics, we concluded that these strains belong to a novel species or a novel genus in the family Microbacteriaceae. Strain IAM $14851^{\mathrm{T}}$ was assigned to the genus Leucobacter on the basis of a 16S rRNA gene sequence comparison. Strain IAM $14851^{\mathrm{T}}$ and the genus Leucobacter share the following chemotaxonomic characteristics: MK-11 is the major menaquinone, branched fatty acids are the major cellular fatty acids and

Table 3. Chemotaxonomic characteristics of isolates

Strains: 1, Z. helvola gen. nov., sp. nov. IAM $14726^{\mathrm{T}}$; 2, Z. alba sp. nov. IAM $14724^{\mathrm{T}}$; 3-5, Z. bifida sp. nov. strains IAM $14848^{\mathrm{T}}$ (3), IAM 15028 (4) and IAM 15029 (5); 6, Z. faecalis sp. nov. IAM $15030^{\mathrm{T}}$; 7, L. komagatae IAM 1093 ${ }^{\mathrm{T}}$; 8, L. albus sp. nov. IAM 14851 ${ }^{\mathrm{T}}$. Abbreviations: 6-DT, 6-deoxytalose; Gal, galactose; Glc, glucose; Hsr, homoserine; Rha, rhamnose.

\begin{tabular}{|c|c|c|c|c|c|c|c|c|}
\hline Feature & 1 & 2 & 3 & 4 & 5 & 6 & 7 & 8 \\
\hline \multicolumn{9}{|c|}{ Menaquinone composition (ratio of peak areas):* } \\
\hline MK-7 & 0 & 14 & 8 & 7 & 5 & 3 & 0 & 0 \\
\hline MK-9 & 88 & 16 & 46 & 38 & 35 & 91 & 0 & 13 \\
\hline MK-10 & 6 & 60 & 0 & 0 & 0 & 1 & 16 & 0 \\
\hline \multicolumn{9}{|c|}{ Cellular fatty acid composition (\%): } \\
\hline $16: 0$ & $17 \cdot 4$ & $30 \cdot 5$ & $17 \cdot 6$ & $17 \cdot 6$ & $18 \cdot 2$ & $10 \cdot 4$ & 0 & $5 \cdot 1$ \\
\hline $\mathrm{i}-16: 0$ & $17 \cdot 9$ & $10 \cdot 9$ & $17 \cdot 0$ & $19 \cdot 3$ & $19 \cdot 7$ & $27 \cdot 3$ & 13 & $23 \cdot 8$ \\
\hline a-15:0 & $41 \cdot 6$ & $37 \cdot 8$ & $49 \cdot 4$ & $47 \cdot 9$ & $43 \cdot 7$ & $42 \cdot 8$ & 65 & $49 \cdot 7$ \\
\hline$a-17: 0$ & $18 \cdot 9$ & $15 \cdot 7$ & $13 \cdot 3$ & $12 \cdot 1$ & $15 \cdot 0$ & $15 \cdot 6$ & 22 & $16 \cdot 3$ \\
\hline
\end{tabular}

${ }^{\star}$ Bold letters indicate predominant components. 


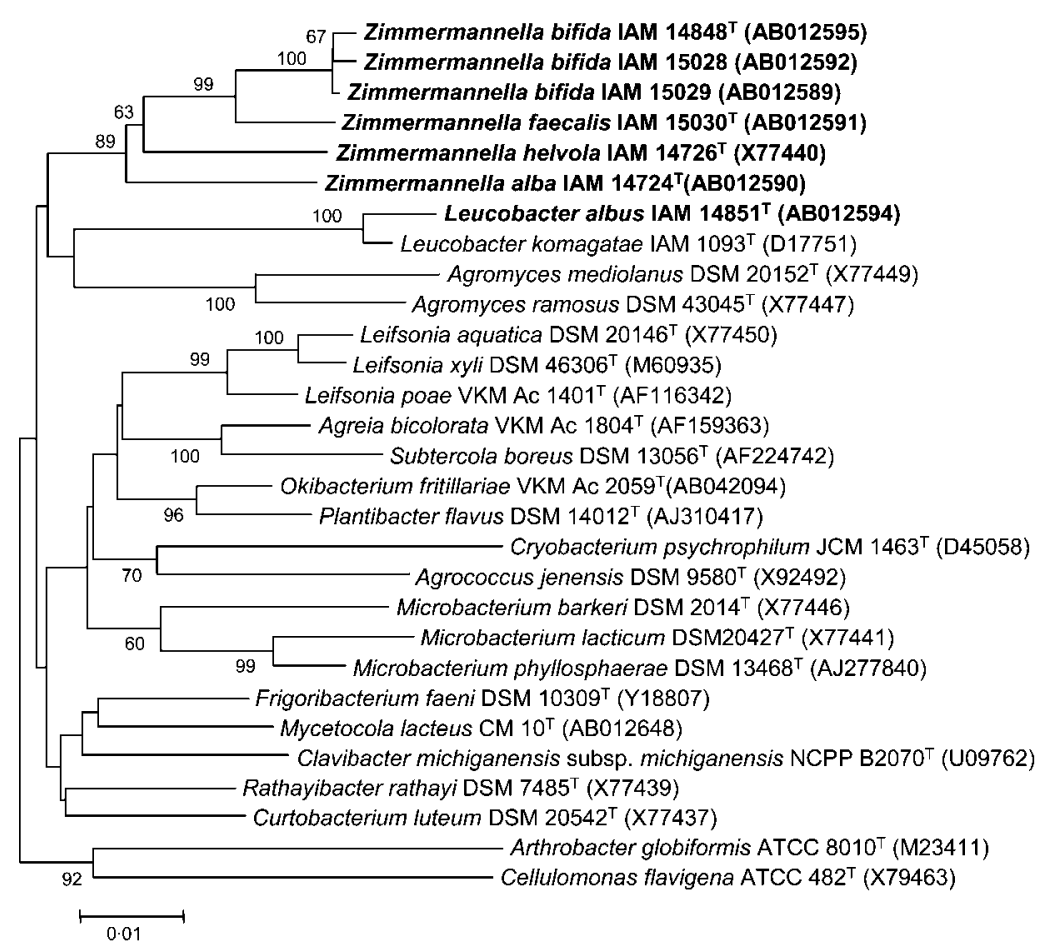

Fig. 2. Phylogenetic tree showing the relationships of Zimmermannella species within the family Microbacteriaceae. The tree is based on a $1440 \mathrm{bp}$ alignment of $16 \mathrm{~S}$ rRNA gene sequences and was constructed using the neighbour-joining method. Numbers at nodes indicate percentages of bootstrap support derived from 1000 replications. $\gamma$-aminobutyric acid is contained in the B-type peptidoglycan of the cell wall. The $\mathrm{G}+\mathrm{C}$ content of the DNA of strain IAM $14851^{\mathrm{T}}(66 \mathrm{~mol} \%)$ is also similar to that of L. komagatae. The $40 \%$ level of DNA relatedness for IAM $14851^{\mathrm{T}}$ and L. komagatae IAM $1093^{\mathrm{T}}$ indicates that they belong to different species. According to Wayne et al. (1987), DNADNA relatedness of $70 \%$ is considered to be the threshold value for the delineation of genomic species; thus, the $40 \%$ level obtained is low enough to justify the separation of strain IAM $14851^{\mathrm{T}}$ and L. komagatae. The strain can also be differentiated from L. komagatae phenotypically (Table 2 ). Hence, strain IAM $14851^{\mathrm{T}}$ can be regarded as a novel Leucobacter species, for which we propose the name Leucobacter albus sp. nov.

The other six strains were collected from urine, wounds, soil, human blood and an unidentified species from the other culture collections. To clarify the taxonomic positions of these bacteria, their morphology, physiology and chemotaxonomic characteristics, together with DNA-DNA relatedness values and 16S rRNA gene sequence comparisons, were used in the present study. The strains were Grampositive, aerobic, non-spore-forming, rod-shaped bacteria with a high G $+\mathrm{C}$ content $(62-68 \mathrm{~mol} \%)$. They also had the following characteristics: the major menaquinone was MK-8, -9 and/or -10 , the diamino acid in the cell wall was $\mathrm{DAB}$ and the muramic acid in the peptidoglycan was of the acetyl type. The results of phylogenetic analysis of the $16 \mathrm{~S}$ rRNA gene sequence revealed that these six strains form a monophyletic and distinct cluster, and that this cluster is independent from any of the subclusters corresponding to established genera within the family Microbacteriaceae. On

Table 4. DNA base composition and DNA relatedness of the isolates

\begin{tabular}{|c|c|c|c|c|c|c|c|}
\hline \multirow[t]{2}{*}{ Strain } & \multirow{2}{*}{$\begin{array}{c}\mathrm{G}+\mathrm{C} \text { content } \\
(\mathrm{mol} \%)\end{array}$} & \multicolumn{6}{|c|}{ DNA relatedness (\%) with: } \\
\hline & & 1 & 2 & 3 & 4 & 5 & 6 \\
\hline 1. Z. helvola IAM $14726^{\mathrm{T}}$ & 67 & 100 & 22 & 13 & 27 & 17 & 23 \\
\hline 2. Z. alba IAM $14724^{\mathrm{T}}$ & 68 & 18 & 100 & 19 & 12 & 21 & 17 \\
\hline 3. Z. bifida IAM $14848^{\mathrm{T}}$ & 62 & 18 & 17 & 100 & 17 & 12 & 16 \\
\hline Z. bifida IAM 15028 & 62 & 10 & 14 & 75 & 15 & 14 & 15 \\
\hline Z. bifida IAM 15029 & 62 & 19 & 20 & 82 & 17 & 16 & 14 \\
\hline 4. Z. faecalis IAM $15030^{\mathrm{T}}$ & 67 & 37 & 19 & 15 & 100 & 12 & 13 \\
\hline 5. L. komagatae IAM $1093^{\mathrm{T}}$ & 66 & 14 & 11 & 19 & 14 & 100 & 40 \\
\hline 6. L. albus IAM $14851^{\mathrm{T}}$ & 66 & 13 & 8 & 19 & 15 & 32 & 100 \\
\hline
\end{tabular}


Table 5. Differential characteristics of genera of the family Microbacteriaceae

Data are from Behrendt et al. (2002), Davis et al. (1984), Evtushenko et al. (2000, 2001, 2002), Groth et al. (1996), Kämpfer et al. (2000), Männistö et al. (2000), Sasaki et al. (1998), Takeuchi et al. (1996), Takeuchi \& Hatano (1998), Tsukamoto et al. (2001), Wieser et al. (1999) and this study. ND, Not determined.

\begin{tabular}{|llllc|}
\hline Genus & \multicolumn{1}{c}{$\begin{array}{c}\text { Diamino } \\
\text { acid }^{*}\end{array}$} & $\begin{array}{c}\text { Acyl } \\
\text { type }\end{array}$ & $\begin{array}{c}\text { Major } \\
\text { menaquinone(s) }\end{array}$ & $\begin{array}{c}\text { G+C content } \\
\text { (mol\%) }\end{array}$ \\
\hline $\begin{array}{l}\text { Zimmermannella } \\
\text { Leucobacter }\end{array}$ & DAB & Acetyl & MK-8-MK-10 & $62-68$ \\
Microbacterium & DAB, GABA & Acetyl & MK-11 & 66 \\
Okibacterium & Lys/Orn & Glycolyl & MK-11-MK-14 & $65-72$ \\
Plantibacter & Lys & Glycolyl & MK-11, MK-12 & 67 \\
Mycetocola & DAB & Acetyl & MK-10, MK-11 & $68-70$ \\
Agrococcus & DAB & Acetyl & MK-9, MK-10 & $64-65$ \\
Cryobacterium & DAB & Acetyl & MK-11, MK-12 & 74 \\
Agromyces & DAB & ND & MK-10 & 65 \\
Leifsonia & DAB & Acetyl & MK-12 & $70-76$ \\
Rathayibacter & DAB & ND & MK-10, MK-11 & $66-73$ \\
Frigoribacterium & DAB & ND & MK-10 & $63-72$ \\
Subtercola & Lys & Acetyl & MK-9 & $71 \cdot 7$ \\
Agreia & DAB & Acetyl & MK-9, MK-10 & $64-68$ \\
Clavibacter & DAB & ND & MK-10 & 67 \\
Curtobacterium & DAB & Acetyl & MK-9, MK-10 & $67-78$ \\
& Orn & Acetyl & MK-9 & $68-75$ \\
\hline
\end{tabular}

${ }^{\star}$ GABA, $\gamma$-Aminobutyric acid; Lys, lysine; Orn, ornithine.

the basis of the above data, these seven strains should belong to a novel genus in the family Microbacteriaceae. Hence, we propose a novel genus, Zimmermannella gen. nov. The characteristics used for differentiation at the genus level between the novel genus and other genera of the Microbacteriaceae are shown in Table 5. In the family Microbacteriaceae, most genera have $\mathrm{DAB}$ as a diamino acid and acetyl-type muramic acid in the peptidoglycan. However, the genus Zimmermannella can be distinguished from the other genera by the major menaquinone and the DNA G $+C$ content. No genera of the Microbacteriaceae have shown MK-8 to MK-10 as the major menaquinones and $\mathrm{G}+\mathrm{C}$ contents from 62 to $68 \mathrm{~mol} \%$, except the genus Zimmermannella.

The six strains in the genus Zimmermannella can be divided into four novel species according to the results of our DNA relatedness test (Table 4). These species can be distinguished from one another on the basis of both their morphological/biochemical characteristics and DNADNA relatedness values. We therefore propose the following classification: strains IAM $14726^{\mathrm{T}}$ and IAM $15030^{\mathrm{T}}$ are the type strains of Zimmermannella helvola sp. nov. and Zimmermannella faecalis sp. nov., respectively, strain IAM $14724^{\mathrm{T}}$ is the type strain of Zimmermannella alba sp. nov. and strains IAM $14848^{\mathrm{T}}$, IAM 15028 and IAM 15029 are members of Zimmermannella bifida sp. nov. Differential characteristics for these four species are summarized in Table 3 .

\section{Description of Zimmermannella gen. nov.}

Zimmermannella (Zim.mer.man'nel.la. N.L. fem. n. Zimmermannella named after O. E. R. Zimmermann, a German microbiologist, who first recognized the species (Brevibacterium helvolum').

Cells are Gram-positive, aerobic, non-motile, short rods or rods. Endospores are not produced. Colonies are circular, convex, smooth and generally white on PY-BHI agar. The optimal temperature for growth is generally $30^{\circ} \mathrm{C}$. Catalase is always produced, while oxidase is only sometimes produced. Nitrate reduction, $\beta$-galactosidase, $\alpha$-glucosidase and aesculin hydrolysis are not found. The cell-wall peptidoglycan contains DAB as a diamino acid, the major cellwall sugar is rhamnose and the muramic acid of the cell wall is of the acetyl type. The major isoprenoid quinones are MK-8 to MK-10. The major fatty acids are $\mathrm{C}_{16: 0}$, iso$\mathrm{C}_{16: 0}$, anteiso- $\mathrm{C}_{15: 0}$ and anteiso- $\mathrm{C}_{17: 0}$. The $\mathrm{G}+\mathrm{C}$ content of the DNA is $62-68 \mathrm{~mol} \%$. Forms an independent phylogenetic cluster in the family Microbacteriaceae. The observed samples have been isolated from human wounds, urine, cow faeces, butter, human blood and soil. The type species is Zimmermannella helvola.

\section{Description of Zimmermannella helvola sp. nov.}

Zimmermannella helvola (hel'vo.la. L. fem. adj. helvola pale yellow). 
Displays the following properties in addition to those given in the genus description. Cells are $0 \cdot 3-0 \cdot 5 \times 0 \cdot 8-$ $1 \cdot 1 \mu \mathrm{m}$ and usually occur in pairs. Two rings are formed on one side of the cells. Oxidase is produced. Acid is produced from rhamnose. The following tests are negative: reduction of nitrite, nitrate respiration, liquefaction of gelatin, urease, alkaline phosphatase and acid production from glycerol, ribose, D-glucose, D-fructose, D-mannose, inositol, mannitol and D-fucose. The cell-wall peptidoglycan contains L- and D-DAB as diamino acids. The major isoprenoid quinone is MK-9. The $\mathrm{G}+\mathrm{C}$ content of the DNA is $67 \mathrm{~mol} \%$.

The type strain, IAM $14726^{\mathrm{T}}\left(=\mathrm{NBRC} 15775^{\mathrm{T}}=\mathrm{DSM}\right.$ $20419^{\mathrm{T}}=$ TISTR $\left.1509^{\mathrm{T}}\right)$, was isolated from butter.

\section{Description of Zimmermannella alba sp. nov.}

Zimmermannella alba (al'ba. L. fem. adj. alba white).

Displays the following properties in addition to those given in the genus description. Cells are $0 \cdot 3-0 \cdot 4 \times 0 \cdot 5-$ $1 \cdot 1 \mu \mathrm{m}$. Oxidase is not produced. Alkaline phosphatase is found. The following tests are negative: reduction of nitrite, nitrate respiration, liquefaction of gelatin, urease and acid production from glycerol, ribose, D-glucose, Dfructose, D-mannose, rhamnose, inositol, mannitol and L-fucose. The cell-wall peptidoglycan contains L-DAB as a diamino acid The major isoprenoid quinone is MK-10. The $\mathrm{G}+\mathrm{C}$ content of the DNA is $68 \mathrm{~mol} \%$.

The type strain, IAM $14724^{\mathrm{T}}\left(=\mathrm{NBRC} 15616^{\mathrm{T}}=\right.$ TISTR $1510^{\mathrm{T}}$ ), was isolated from human urine.

\section{Description of Zimmermannella bifida sp. nov.}

Zimmermannella bifida (bi'fi.da. L. fem. adj. bifida divided into two parts).

Displays the following properties in addition to those given in the genus description. Cells are $0 \cdot 3-0 \cdot 4 \times 1 \cdot 5-$ $3.0 \mu \mathrm{m}$. Branched shapes are formed. Oxidase is not produced. Alkaline phosphatase is produced. The following tests are negative for all strains: reduction of nitrite, nitrate respiration, liquefaction of gelatin, urease and acid production from glycerol, D-glucose, D-fructose, D-mannose, inositol, mannitol and L-fucose. The cell-wall peptidoglycan contains L-DAB as a diamino acid. The major isoprenoid quinones are MK-8 and MK-9. The G $+\mathrm{C}$ content of the DNA is $62 \mathrm{~mol} \%$.

The samples observed were isolated from human wounds, human blood and soil. The type strain is IAM $14848^{\mathrm{T}}$ $\left(=\right.$ TISTR $\left.1511^{\mathrm{T}}\right)$.

Description of Zimmermannella faecalis sp. nov.

Zimmermannella faecalis (fae.ca'lis. N.L. fem. adj. faecalis faecal).

Displays the following properties in addition to those given in the genus description. Cells are $0 \cdot 3-0 \cdot 4 \times 0 \cdot 5-$ $1 \cdot 1 \mu \mathrm{m}$. Oxidase is produced. Acid is produced from D-glucose, D-fructose, D-mannose, rhamnose, inositol and mannitol. The following tests are negative: reduction of nitrite, nitrate respiration, liquefaction of gelatin, urease, alkaline phosphatase and acid production from glycerol, ribose and L-fucose. The cell-wall peptidoglycan contains $\mathrm{L}-\mathrm{DAB}$ as a diamino acid. The major isoprenoid quinone is MK-9. The G $+\mathrm{C}$ content of the DNA is $67 \mathrm{~mol} \%$.

The type strain, IAM $15030^{\mathrm{T}}\left(=\mathrm{NBRC} 15706^{\mathrm{T}}=\mathrm{ATCC}\right.$ $13722^{\mathrm{T}}=$ TISTR $\left.1514^{\mathrm{T}}\right)$, was isolated from cow faeces.

\section{Description of Leucobacter albus sp. nov.}

Leucobacter albus (al'bus. L. masc. adj. albus white).

Cells are Gram-positive, aerobic rods, $0 \cdot 3-0 \cdot 4 \times 0 \cdot 5-$ $1 \cdot 1 \mu \mathrm{m}$, non-sporulating and non-motile. Smooth, white colonies are produced on PY-BHI agar. The optimal temperature for growth is $30^{\circ} \mathrm{C}$. Catalase is produced, but oxidase is not. Acid is produced from glycerol, ribose and L-fucose. The following tests are negative: reduction of nitrate or nitrite, nitrate respiration, liquefaction of gelatin, hydrolysis of aesculin, urease, alkaline phosphatase, $\beta$-galactosidase and $\alpha$-glucosidase and acid production from D-glucose, D-fructose, D-mannose, rhamnose, inositol and mannitol. The cell-wall peptidoglycan contains L-DAB and $\gamma$-aminobutyric acid; the muramic acid of the cell wall is of the acetyl type. The major isoprenoid quinone is MK-11. The major fatty acids are anteiso- $\mathrm{C}_{15: 0}$, anteiso- $\mathrm{C}_{17: 0}$ and iso- $\mathrm{C}_{16: 0}$. The $\mathrm{G}+\mathrm{C}$ content of the DNA is $66 \mathrm{~mol} \%$.

The type strain, IAM $14851^{\mathrm{T}}$ ( = TISTR $1515^{\mathrm{T}}$ ), was isolated from soil.

\section{NOTE ADDED IN PROOF}

After this paper was accepted for publication, the description of Pseudoclavibacter helvolus for 'Brevibacterium helvolum’ DSM 20419 was published (Manaia et al., 2004).

\section{ACKNOWLEDGEMENTS}

The authors would like to thank Dr K. Suzuki for enantiomeric analysis of cell-wall amino acids. We are grateful to Professor H. G. Trüper (University of Bonn, Bonn, Germany) for his help in the latinization of the new genus and species names.

\section{REFERENCES}

Behrendt, U., Ulrich, A., Schumann, P., Naumann, D. \& Suzuki, K. (2002). Diversity of grass-associated Microbacteriaceae isolated from the phyllosphere and little layer after mulching the sward; polyphasic characterization of Subtercola pratensis sp. nov., Curtobacterium herbarum sp. nov. and Plantibacter flavus gen. nov., sp. nov. Int J Syst Evol Microbiol 52, 1441-1454. 
Collins, M. D. \& Jones, D. (1981). The distribution of isoprenoid quinone structural types in bacteria and their taxonomic implications. Microbiol Rev 45, 316-354.

Davis, M. J., Gillaspsie, A. G., Jr, Vidaver, A. K. \& Harris, R. W. (1984). Clavibacter: a new genus containing some phytopathogenic coryneform bacteria, including Clavibacter xyli subsp. xyli sp. nov., subsp. nov. and Clavibacter xyli subsp. cynodontis subsp. nov., pathogens that cause ratoon stunting disease of sugarcane and Bermudagrass stunting disease. Int J Syst Bacteriol 34, 107-117.

Evtushenko, L. I., Dorofeeva, L. V., Subbotin, S. A., Cole, J. R. \& Tiedje, J. M. (2000). Leifsonia poae gen. nov., sp. nov., isolated from nematode galls on Poa annua, and reclassification of 'Corynebacterium aquaticum' Leifson 1962 as Leifsonia aquatica (ex Leifson 1962) gen. nov., nom. rev., comb. nov. and Clavibacter xyli Davis et al. 1984 with two subspecies as Leifsonia xyli (Davis et al. 1984) gen. nov., comb. nov. Int J Syst Evol Microbiol 50, 371-380.

Evtushenko, L. I., Dorofeeva, L. V., Dobrovolskaya, T. G., Streshinskaya, G. M., Subbotin, S. A. \& Tiedje, J. M. (2001). Agreia bicolorata gen. nov., sp. nov., to accommodate actinobacteria isolated from narrow reed grass infected by the nematode Heteroanguina graminophila. Int J Syst Evol Microbiol 51, 2073-2079.

Evtushenko, L. I., Dorofeeva, L. V., Krausova, V. I., Gavrish, E. Y., Yashina, S. G. \& Takeuchi, M. (2002). Okibacterium fritillariae gen. nov., sp. nov., a novel genus of the family Microbacteriaceae. Int J Syst Evol Microbiol 52, 987-993.

Ezaki, T., Hashimoto, Y. \& Yabuuchi, E. (1989). Fluorometric deoxyribonucleic acid-deoxyribonucleic acid hybridization in microdilution wells as an alternative to membrane filter hybridization in which radioisotopes are used to determine genetic relatedness among bacterial strains. Int J Syst Bacteriol 39, 224-229.

Felsenstein, J. (1985). Confidence limits on phylogenies: an approach using the bootstrap. Evolution 39, 783-791.

Groth, I., Schumann, P., Weiss, N., Martin, K. \& Rainey, F. A. (1996). Agrococcus jenensis gen. nov., sp. nov., a new genus of actinomycetes with diaminobutyric acid in the cell wall. Int J Syst Bacteriol 46, 234-239.

Harper, J. J. \& Davis, G. H. G. (1979). Two-dimensional thin-layer chromatography for amino acid analysis of bacterial cell walls. Int J Syst Bacteriol 29, 56-58.

Kämpfer, P., Rainey, F. A., Andersson, M. A., Nurmiaho Lassila, E.-L., Ulrych, U., Busse, H.-J., Weiss, N., Mikkola, R. \& SalkinojaSalonen, M. (2000). Frigoribacterium faeni gen. nov., sp. nov., a novel psychrophilic genus of the family Microbacteriaceae. Int J Syst Evol Microbiol 50, 355-363.

Kimura, M. (1980). A simple method for estimating evolutionary rates of base substitutions through comparative studies of nucleotide sequences. J Mol Evol 16, 111-120.

Manaia, C. M., Nogales, B., Weiss, N. \& Nunes, O. C. (2004). Gulosibacter molinativorax gen. nov., sp. nov., a molinate-degrading bacterium, and classification of 'Brevibacterium helvolum' DSM 20419 as Pseudoclavibacter helvolus gen. nov., sp. nov. Int J Syst Evol Microbiol 54, 783-789.

Männistö, M. K., Schumann, P., Rainey, F. A., Kämpfer, P., Tsitko, I., Tiirola, M. A. \& Salkinoja-Salonen, M. S. (2000). Subtercola boreus gen. nov., sp. nov. and Subtercola frigoramans sp. nov., two new psychrophilic actinobacteria isolated from boreal groundwater. Int J Syst Evol Microbiol 50, 1731-1739.

Mikami, H. \& Ishida, Y. (1983). Post-column fluorometric detection of reducing sugars in high-performance liquid chromatography using arginine. Bunseki Kagaku 32, E207-E210.

Park, Y. H., Suzuki, K., Yim, D. G. \& 7 other authors (1993). Suprageneric classification of peptidoglycan group B actinomycetes by nucleotide sequencing of $5 \mathrm{~S}$ ribosomal RNA. Antonie van Leeuwenhoek 64, 307-313.

Saitou, N. \& Nei, M. (1987). The neighbor-joining method: a new method for reconstructing phylogenetic trees. Mol Biol Evol 4, 406-425.

Sasaki, J., Chijimatsu, M. \& Suzuki, K.-I. (1998). Taxonomic significance of 2,4-diaminobutyric acid isomers in the cell wall peptidoglycan of actinomycetes and reclassification of Clavibacter toxicus as Rathayibacter toxicus comb. nov. Int J Syst Bacteriol 48, 403-410.

Schleifer, K. H. \& Kandler, O. (1972). Peptidoglycan of bacterial cell walls and their taxonomic implications. Bacteriol Rev 36, 407-477.

Stackebrandt, E., Rainey, F. \& Ward-Rainey, N. L. (1997). Proposal for a new hierarchic classification system, Actinobacteria classis nov. Int J Syst Bacteriol 47, 479-491.

Suzuki, K., Sasaki, J., Uramoto, M., Nakase, T. \& Komagata, K. (1997). Cryobacterium psychrophilum gen. nov., sp. nov., nom. rev., comb. nov., an obligately psychrophilic actinomycete to accommodate 'Curtobacterium psychrophilum' Inoue and Komagata 1976. Int J Syst Bacteriol 47, 474-478.

Takagi, H., Shida, O., Kadowaki, K., Komagata, K. \& Udaka, S. (1993). Characterization of Bacillus brevis with descriptions of Bacillus migulanus sp. nov., Bacillus choshinensis sp. nov., Bacillus parabrevis sp. nov., and Bacillus galactophilus sp. nov. Int J Syst Bacteriol 43, 221-231.

Takeuchi, M. \& Hatano, K. (1998). Union of the genera Microbacterium Orla-Jensen and Aureobacterium Collins et al. in a redefined genus Microbacterium. Int J Syst Bacteriol 48, 739-747.

Takeuchi, M., Weiss, N., Schumann, P. \& Yokota, A. (1996). Leucobacter komagatae gen. nov., sp. nov., a new aerobic Grampositive, nonsporulating rod with 2,4-diaminobutyric acid in the cell wall. Int J Syst Bacteriol 46, 967-971.

Thompson, J. D., Higgins, D. G. \& Gibson, T. J. (1994). CLUSTAL W: improving the sensitivity of progressive multiple sequence alignment through sequence weighting, position-specific gap penalties and weight matrix choice. Nucleic Acids Res 22, 4673-4680.

Tsukamoto, T., Takeuchi, M., Shida, O., Murata, H. \& Shirata, A. (2001). Proposal of Mycetocola gen. nov. in the family Microbacteriaceae and three new species, Mycetocola saprophilus sp. nov., Mycetocola tolaasinivorans sp. nov. and Mycetocola lacteus sp. nov., isolated from cultivated mushroom, Pleurtus ostreatus. Int J Syst Evol Microbiol 51, 937-944.

Uchida, K. \& Aida, A. (1977). Acyl type of bacterial cell wall: its simple identification by colorimetric method. J Gen Appl Microbiol 23, 249-260.

Wako Pure Chemical Industries (1989). Technical Note on the System of PTC-amino Acid Analysis. Osaka: Wako Pure Chemical Industries (in Japanese).

Wayne, L. G., Brenner, D. J., Colwell, R. R. \& 9 other authors (1987). International Committee on Systematic Bacteriology. Report of the ad hoc committee on reconciliation of approaches to bacterial systematics. Int J Syst Bacteriol 37, 463-464.

Wieser, M., Schumann, P., Martin, K., Altenburger, P., Burghardt, J., Lubitz, W. \& Busse, H.-J. (1999). Agrococcus citreus sp. nov., isolated from a medieval wall painting of the chapel of castle Herberstein (Austria). Int J Syst Bacteriol 49, 1165-1170.

Yokota, A., Takeuchi, M., Sakane, T. \& Weiss, N. (1993). Proposal of six new species in the genus Aureobacterium and transfer of Flavobacterium esteraromaticum Omelianski to the genus Aureobacterium as Aureobacterium esteraromaticum comb. nov. Int J Syst Bacteriol 43, 555-564. 